\title{
東海地方における近世密教系仏堂の外陣架構について DESIGN AND CONSTRUCTION OF BEAM SYSTEM IN “GEJIN" OF THE BUDDHIST HALLS OF THE ESOTERIC BUDDHIST TEMPLE IN TOKAI DISTRICT IN THE EDO PERIOD
}

\author{
岩田敏也* \\ Toshiya IWATA
}

\begin{abstract}
The aim of this research is to clarify the characteristic of the design and construction of beam system in the main halls of the Esoteric Buddhist temple in TŌKAI district in the Edo period. The conclusions are as follows.

1) There are some common distinctions of the beam system in "Gejin" (the outer chamber) of the Buddhist halls in this district in the Edo period, by which these Buddhist halls can be classified.

2) Some Buddhist halls adopted the Rainbow-beam of 3-pillar spans in the lengthwise direction of it, especially in the eastern part of MIKAWA and TÖTOUMI areas.

3) These beam systems has developed still more in the Edo period, inheriting technical skills from the Medieval period. It has become more complicated with gigantic beams in structure.
\end{abstract}

Keywords : Edo period, Esoteric Buddhist temple, Buddhist hall, Gejin,. Beam system, 江戸時代、密教寺院、仏堂、外陣、架構

\section{1.はじめに}

密教寺院の仏堂は、中愢に外陣と内陣を区画しながら奥行の深い 平面を成立させ、それに伴って、堂内の架構も新たな進展をみせた。 特に礼拝空間である外陣の架構は、構造的にも意压的にも、目覚し い発展を遂げたことはよく知られている1!。近世における密教系の 仏堂もそれを継承していると考えられているが、その実態は未だ究 明されたとは言い難い2)。

筆者はこれまで、近世密教系仏堂の架構について、『尾張・美濃地 方における近世密教系仏堂の架構について』・『松阪市・朝田寺本堂 について』・『茨城県の近世密教系仏堂について』・『新舄県の近世密 教系仏堂について』・岡山県の密教系仏堂について』・『近世密教系 仏堂の架構意匠の研究 - 豊川市・財賀寺本堂について - 』・『近世密 教系仏堂の架構意匠の研究 - 尾張の笠覆寺本堂について - 『・四 国・松山市の蓮華寺本堂と浄瑠唡寺本堂の外陣架構について』等 ${ }^{31}$ を発表し、近世密教系仏堂の架構には、中世の伝統を引き継ぎなが らも、建築的な発展や地域的な特色がみられることを論じてきた。 中でも東海地方の遺構には、注目される点が多く見られたので、こ の地域の近世密教系仏堂の架構について再調查を行うた ${ }^{4)}$ 。その結 果、新たな知見を得ることができたので、本稿では、東海地方の遺 構（七間堂と五間堂）の外陣架構を中心に考察し、近世密教系仏堂
の特徴の一端を明らかにしたい。なお、七間堂と五閒堂を研究対象 としたのは、この規模の堂が、中世・近世を通じて密教寺院の主要 堂宇とされてきたからである5)。更に、密教仏堂と類似の架構形式

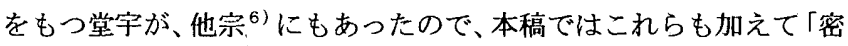
教系仏堂」として検討することとした。

\section{2. 東海地方における近世密教系仏堂の遗構}

本稿では、遠江・三河・尾張・美濃・伊勢の地域を対象とし、こ の地方に残る近世の密教系仏堂として、表一 1 に示す 26 棟の遺構 を取り上げる。

各仏堂の建立年代をみると、桃山期の遺構が 1 棟、江戸時代の遺 構では、17 世紀前半のもの 2 棟、17 世紀後半のもの 6 棟、18 世紀 前半のもの 8 棟、18 世紀後半のもの 6 棟、19 世紀前半のもの 3 棟 と、江戸初期から後期に亘って広く残されており、この種の仏堂が 近世を通じて継続的に建立されていたとみられる。宗派別では、真 言宗の仏堂が 14 棟、天台宗が 6 棟あり、密教以外で取り上げたも のは、臨済宗と日蓮宗が各 2 棟、曹洞宗と浄土宗が各 1 棟である。 このうち臨済宗の 2 ケ寺は、古くは真言宗であった。次に各仏堂の 規模をみると、七間堂は 26 棟中 2 棟のみで、他は全て五間堂であ る。また、遺構は当地域内に広く分布しており、中でも東三河から 
遠江地域には比較的よく残っていて、全国的にも近世密教系仏堂の 遺構が多い地方であるとみられる。

表 - 1 東海地方の近世密教系仏堂一覧 （建立年代順）

\begin{tabular}{|c|c|c|c|c|}
\hline 寺院・厔 & 论 & 宗 派 & 規模 & 所 在 地 \\
\hline 金㴊證寺本堂 重文 & 慶長 15 年(1610) 棟札 & 臨済 7) & & \\
\hline 実成寺本堂 & 江户時代初期 & 日蓮 ${ }^{81}$ & 5 間 $\times 6$ 間 & 愛知県甚目寺 \\
\hline 応賀寺薬師堂 県文 & 寛永 18 年(1641) & 真言 & 5 間 $\times 5$ 間 & 静岡県新居町 \\
\hline 観福寺本堂 & 寛文 5 年(1665) 棟札 & 天台 & 5 間 $\times 5$ 閒 & 愛知県東海市 \\
\hline 法明寺薬師堂 & 寛文 7 知(1667) 棟札 & 天台 & 5 間 $\times 5$ 間 & 岐阜! \\
\hline 横藏寺本堂 & 寛文 10 年(1670）寺記 & 天台 & 5 間 $\times 5$ 間 & 岐阜県谷汲村 \\
\hline 日龍䇣寺本堂 & 延宝 2 年(1674) 寺記 & 真言 & 5 間 $\times 4$ 間 & 岐帛県 \\
\hline 普門寺本堂 & 元禄 6 年(1693) 棟札 & 真言 & 5 間 $\times$ & 愛知出 \\
\hline 地蔵院本堂 & 元禄 13 年(1700) 棟札 & 真言 & 5 間 $\times 4$ 間 & 三重県関町 \\
\hline 甲山寺護摩堂 & 元禄 16 年(1703) 寺記 & 天台 & 5 間 $\times 5$ 間 & 愛知県岡崎市 \\
\hline 大福寺本堂 & 宝水 4 年(1707) 寺記 & 真言 & 5 間 $\times 5$ 間 & 静䎟県 \\
\hline 東観音寺観音堂 & 宝永 7 年(1710) 棟札 & 臨済9) & 5 間 $\times 4$ 間 & 要知県䌡橋市 \\
\hline 西楽寺本堂 & 18 世紀前半頃 & 真言 & 5 間 $\times 5$ 間 & 静岡県袋井市 \\
\hline 三明寺本堂 & 正徳 2 年(1712) 棟札 & 曹洞 10) & 5 間 $\times 5$ 間 & 愛知県豊川市 \\
\hline 油山寺薬師堂 県文 & 元文 4 年(1739) 棟札 & 真言 & 5 間 $\times 5$ 問 & 静岡県袋井市 \\
\hline 鴠江寺本堂 & 18 世紀前半頃 & 真言 & 5 間 $\times 6$ 間 & 静岡県浜松市 \\
\hline 妙立寺本堂 & 延享 4 年(1747) 寺記 & 日蓮 ${ }^{11}$ & 5 間 $\times 5$ 間 & 静岡県湖西市 \\
\hline 大御堂寺本堂 & 宝曆 4 年(1754) 棟札 & 真言 & 5 閒 $\times 5$ 間 & 愛知県美浜町 \\
\hline 笠㠅寺本堂 & 宝暦 13 年(1763) 寺記 & 真言 & 7 間 $\times 7$ 間 & 愛知県名古屋 \\
\hline 摩訶耶寺本堂 & 18 世紀後半頃 & 真言 & 5 間 $\times 5$ 間 & 静岡県三ケ日 \\
\hline 富賀寺本堂 & 寛政 5 年(1793) 寺記 & 真言 & 5 間 $\times 5$ 間 & 愛知県新城市 \\
\hline 真福寺本堂 & 寛政 5 年(1793) 寺記 & 天台 & 5 間 $\times 7$ 閒 & 要知異岡崎市 \\
\hline 長久寺本堂 & 寬政 7 年(1795) 寺記 & 真言 & 5 間 $\times 5$ 間 & 愛知県名古屋 \\
\hline 財賀寺本堂 & 文政 6 年(1823) 棟札 & 真言 & 5 間 $\times 5$ 間 & 票知県豊川市 \\
\hline 願成寺薬師堂 & 天保 2 年(1831) 寺記 & 天台 & 5 關 $\mathrm{x}$ & 愛知県名古屋 \\
\hline 曼陀羅寺曼陀羅堂 & 弘化(1844-47) 頃 & 浄士 ${ }^{121}$ & 5 間 $\times 5$ 間 & 愛知県江南市 \\
\hline
\end{tabular}

\section{3. 架構及び平面による分類}

中世の密教仏堂は、外陣と内陣、そして脇陣・後陣などから成る 正方形に近い平面をもち、各室の規模や構成、架構等において多様 な発展を示した。とりわけ外陣に関しては、その傾向が顕著であり、 それまでの和様に大仏様・禅宗様の手法を加え、入側柱を省略しな がら虹梁を渡し、架構を空間構成や意匠に用いる進展をみせた。そ して、外陣の抎張化・荘厳化の動きが進み、虹梁・蟇股・大瓶束・ 海老虹梁、斗栱や天井形式など、装飾的技法を巧みに組み合わせ、 各地に斬新で多彩な意匠の仏堂が建立されたことは周知の通りであ る ${ }^{13)}$ 。

そこで本稿では、架構形式・入側柱の数・天井形式・外陣奥行の 4 項目について各仏堂の形態分類を試み、以下この分類（表 - 2) に従って、その特色を探ってみた。

\section{（1）外陣に架搆を見せる仏堂}

$\mathrm{A}$ : 外陣奥行 2 間で入側隅柱のみ立て、桁行 3 間大虹梁を用いる 堂

これに分類される遺構は 7 棟あり、いずれも地域的には東三河か ら遠江に分布し、時代的には江戸初期から後期に亘ってみられる。

このうち最も建立年代の古い忘賀寺薬師堂（写真-1）14 は、外 陣に入側隅柱 2 本を立て、同柱間の頭貫位置に析行 3 間の大虹梁を 渡している。虹梁上には直接平三斗を載せ、外陣前面の側柱上斗棋 （出三斗）との間を海老虹梁で㢣ぎ、内陣正面の両端柱と入側隅柱 の間には頭貫 - 台輪を渡して身舎を固め、入側隅柱から外陣の正面 側面 2 万の側柱に向けて水平の槃虹梁を入れる。天井は庇部分を化 精屋根裹、身舎部分を鏡天井とする。

普門寺本堂 (図-1)・西楽寺本堂 (写真-2) ・油山寺薬師堂 (図 $-2 ） の 3$ 棟の外陣も、応賀寺薬師堂と同様、入側隅柱を 2 本立て、 この間に衍行 3 閭虹梁を渡す架構を示すが、普門寺と西楽寺では桁 行 3 間虹梁上に台輪を載せ、その上に斗栱を置く。更に、西楽寺と 油山寺では入側隅柱と内陣正面柱との間に梁行 1 間の内法虹梁を架 け、上部の頭貫とこの虹梁間の中備に蟇股を入れる。また、3 棟と も入側隅柱から外陣正面側面 2 方の側柱一海老虹梁を渡しており、 応賀寺の外陣架構よりも装飾的な扱いが増している。

鴨江寺本堂（写真－3）の外陣では、析行 3 閒の大振りな虹梁を 入側䧉柱間の内法位置に架け、柱頂に汇頭貫・台輪が通され、頭貫 と桁行 3 間虹梁間には中央に䓪股、その両脇（正面側柱筋位置）に は大瓶束が置かれる。また、入側隅柱から側面側柱と内陣正面の柱 へも内法虹梁が架かり、更に海老虹梁が入側隅柱上の斗栱から外陣 の正面側面 2 万の側柱と、桁行 3 問虹梁上の大瓶束上斗棋加外陣 正面側柱へ渡される。

摩訶耶寺本堂（図-3・写真- 4) は、外陣側面の柱間寸法を大 きくとり、更に入側柱の位置を側面側柱とずらして立てている。入 側隅柱間には、頭貫位置に析行 3 間虹梁と台輸を渡しているが、庇 の幅が比較的狭いことと、側面の柱筋が合わないこともあって、身 舎から側柱への熬虹梁は一切用いていない。また、天井は身舎部分 を格天井とし、庇部分で注身舎との高低差を支輪で処理した折上格 天井としている。この堂の外陣では、析行 3 間虹梁を使用しながら も、海老虹梁を用いない点と、庇部分に化粧屋根裏を見せない点に 特色がある。

財賀寺本堂 (図-4・写真- 5 ) は江戸時代後期の大型五間堂で、 やはり外陣奥行の柱閒寸法を大きくとり、側面では前端間の垂木枝 数を 20 枝、第 2 間を 23 枝とする。外陣前面では、中央の柱間枝数 を 32 枝、その両脇間を 17 枝、両端間を 18 枝とし、中央柱間を殊 更広くとる。これに対し、外陣内の入側隅柱は、同柱閒の垂木枝数

表 - 2 外陣の架構及び平面構成による分類表

\begin{tabular}{|c|c|c|c|c|c|}
\hline 分類記号 & 入側柱 & 外 陣 架 構 & 外陣天井形 式 & 奥行 & 遗 構 \\
\hline A & 2 本 & 桁行 3 間大虹梁 & 身舎：鏡又は格天井 & 2 間 & $\begin{array}{l}\text { 応賀寺薬師堂・普門寺本堂・西楽寺本堂・油山寺薬師堂 } \\
\text { 鴠江寺本堂・摩訶耶寺本堂・財賀寺本堂 }\end{array}$ \\
\hline $\mathrm{B}-1$ & なし & 梁行 2 間虹梁+桁行 3 間大虹梁 & 身舍：鏡又は格天井 & 2 間 & 日龍峯寺本堂・明寺本堂・妙立寺本堂・富賀寺本堂 \\
\hline $\mathrm{B}-2$ & なし & 梁行 2 間虹梁 & $\begin{aligned} \text { 身舎 : 鏡又は格天井 } \\
\text { 又は小組格天井 }\end{aligned}$ & 2 間 & $\begin{array}{l}\text { 金测證寺本堂・実成寺本堂・観福寺本堂・横藏寺本堂 } \\
\text { 大御堂寺本堂 }\end{array}$ \\
\hline $\mathrm{B}-2^{\prime}$ & なし & 梁行 2 間虹梁 & 舟底天井 & 2 間 & 法明寺薬師堂・真福寺本堂 \\
\hline $\mathrm{C}$ & なし & 梁行 3 間虹梁 & 庇：化精 身菩：格天开 & 3 間 & 笠覆寺本堂 \\
\hline $\mathrm{D}$ & 4 本 & 見せない & 庇 : 格天井 身舎 : 小組格天井 & 2 間 & 大福寺本堂 \\
\hline $\mathrm{E}$ & なし & 見せない & 一面 格天井 & 2 間 & 甲山寺護摩堂 - 東観音寺観音堂 - 原成寺本堂 \\
\hline F & なし & 見せない & 一面 鏡又は格天井 & 1 間 & 地蔵院本堂 - 長久寺本堂 - 曼陀羅寺曼抡羅堂 \\
\hline
\end{tabular}


を 64 枝とし、内陣正面 3 間の見付幅と一致させ、しかも化粧隅木 が真隅に納まるように、析行・梁行とも側柱までの垂木枝数が 19 枝となる位置に立っている。このように財賀寺では外陣の前面と側 面の側柱を入側隅柱位犆と無関係に配した点に特徵がある。

外陣の架構については、鴨江寺と同様、入側隅柱間の内法位置に 巨大な桁行 3 間虹梁を渡し、上に大瓶束を置いて頭貫・台輪を通し、 その上に 8 枝間隔で出組の詰組を載せる。また入側隅柱から内陣正 面両端の柱へ、梁行 1 間の内法虹梁・頭貫・台輪を渡して身舎を固 める。天井は庇を化粧屋根哀、身舎を格天井とする。財賀寺の外陣 では、身舎と庇の慗ぎに海老虹梁が一切使われず、入側隅柱間の内 法に架けられた析行 3 間虹梁の巨大さが目立ち、柱の配置法なども 合わせ、時代の新しさが認められる。

$\mathrm{B}$ ：外陣に入側柱を立てず、架構を見せる堂

Bに分類されるのは、11 棟の遺構である。これを外陣架椿の特徵 によって更に細分すると、Aでもみられた桁行 3 閒の大虹梁を用い る架構法を採る堂が存在するので、これを B-1 とし、析行 3 間虹 梁を使わないものを B-2とした。また B-2のうち、外陣全体を 寄棟型の舟底天井とするものがあり、これを B-2’とした。

B-1：入側柱を立てず、梁行 2 間虹梁と桁行 3 間虹梁を併用す る堂

この分類の堂は、奥行 2 間の外陣内に入側柱を 1 本も立てず、内 陣正面の両端身舎柱加外陣前面側柱一梁行 2 間虹梁を架け、この 2 挺の虹梁上の化粧隅木が真隅に納まる位置に支点を設け、この支 点間に桁行 3 間の大虹梁を渡す架構法を採るものであり、4 棟の遺 構がこれに属する。

日龍峯寺本堂（写真一6） は懸崖に建つ影造りの堂で、外陣内の 2 挺の梁行 2 間虹梁上に板菳股と三斗組を載せて支点とし、この間 に析行 3 間の大虹梁を渡す。また、この虹梁はそのまま前面庇部分 の化粧屋根裹天井の垂木を受け、虹梁より奥の身舎部分には鏡天井 を張る。建立年次が 4 棟中、最も古いこともあってか、入倒桁をそ のまま析行 3 間虹梁としたもので、過飾に陥ることなく、簡潔な外 陣である。

三明寺本堂（図- $5 \cdot$ 写真一 -7 ）の外陣では、内陣正面の雨端身 舎柱から外陣前面側柱八梁行 2 間の虹梁を架け、この虹梁上中央 (化 粧隅木が真隅に納まる位置) に大瓶束を立てる。この大瓶束頂を桁 行 3 間虹梁と台輪で遙ぎ、台輪上には各側柱筋位置に出組斗栱を置 く。大瓶束加らは、外陣側柱一向けて标行 - 梁行・隅行の 3 方向 海老虹梁を架ける。また、桁行 3 間虹梁加ら外陣前面中央の側柱へ
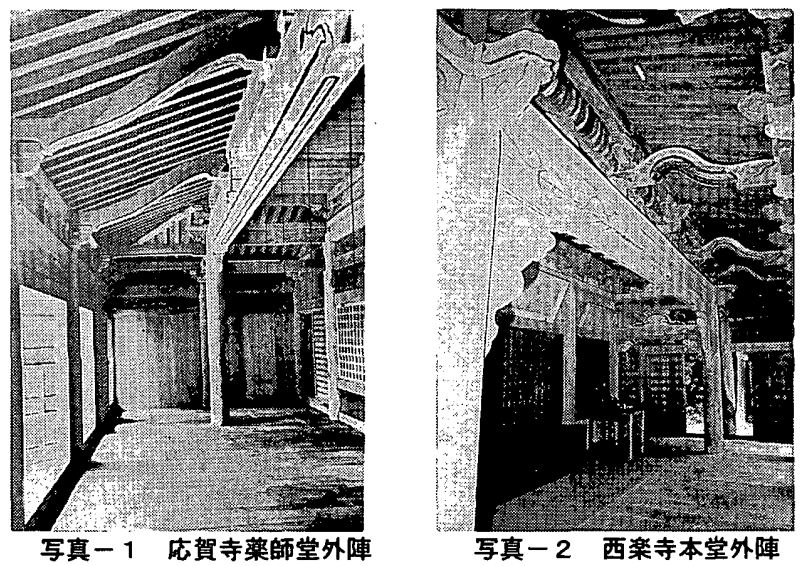

向けても海老虹梁が渡され、外陣庇部分には都合 8 挺の海老虹梁が 架けられる。この他、内陣正面の中央 2 本の柱加ら析行 3 閒虹梁上 の斗栱へも梁行 1 間の虹梁を渡し、この虹梁上中央に撥束を置いて 天井迴縁を受け、外陣身舎部分を 3 分して格天井を張り、正側 3 方 の庇部分は化粧屋根裏とする。ここでは、梁行 2 閒虹梁・桁行 3 間 虹梁・海老虹梁を三段に組上げた複雑な架構が特徽である。

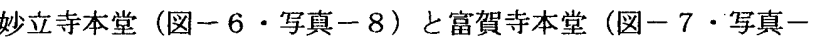
9) の外陣でも、内陣正面の両端身舎柱から外陣前面側柱一梁行 2 間の虹梁を架け、この虹梁上中央に大瓶束を立てる。この大瓶束間 に、妙立寺では内法位犆に、菅賀寺では頭貫位置に、それぞれ析行 3 間虹梁を渡し、前者では析行 3 間虹梁上の 3 分点にも大瓶束を立 て、束頂に頭貫を通してその上に台輪を置く。後者では析行 3 間虹 梁上に直接台輪を置く。身舎と庇の慗ぎには、妙立寺では梁行 2 間 虹梁上の大瓶束から外陣の正面側面 2 方の側柱一、更に桁行 3 間虹 梁上の大瓶束から正面侧柱へそれぞれ海老虹梁を架ける。富賀寺で は梁行 2 閒虹梁上の大瓶束小ら梁行・析行・隅行の 3 方へ水平虹梁 を渡し、桁行 3 閒虹梁上の斗栱から外陣前面側柱へは海老虹梁を架 ける。天井は庇部分を雨堂とも化粧屋根裹、身舎部分は妙立寺が格 天井、富賀寺が小組格天井とする。

日龍篻寺本堂以外は、東三河・遠江の遺構であり、梁行 2 間虹梁・ 桁行 3 間虹梁・海老虹梁を三段に組上げる架構を見せる点に共通の 特色がある。

以上、 $\mathrm{A}$ と $\mathrm{B}-1$ に分類された遺構 11 棟の外陣架構の概要を述 べたのであるが、このうち 10 棟が東三河・遠江の遺構であり、当 地域では、外陣に桁行 3 閒の大虹梁を用いる架構法が一般的であっ た。しかも、このような架構法は、他の地方の近世密教系仏堂には 類例 ${ }^{15)}$ が少なく、当地方に扝ける地域的な特色の一つであるとい えよう 16)。

中世仏堂で、析行 3 間虹梁を用いた先駆的遺構としては、善水寺 本堂（滋賀県甲西町：室町前期）17) など数棟が知られている。善水 寺本堂は桁行 7 間 $\times$ 梁間 5 間の仏堂で、外陣奥行を 2 間とし、入側 柱列の中央 2 本の柱を抜き、この間の頭貫位置に桁行 3 閒の虹梁を 渡すもので、Aの分類でみられた架構法の先例といえよう。また、 当地方に批ては、岐阜県関市の新長谷寺本堂（写真－19）（長禄 4 年/1460） ${ }^{18}$ が、外陣に桁行 3 閒の虹梁を採用している。新長谷 寺本堂は析行・梁間ともに 5 間の仏堂で、奥行 2 閒の外陣内には入 側柱を 1 本も立てず、内陣正面雨端の身舎柱から外陣前面側柱一梁 行 2 間の虹梁を架け、その上に板幕股と三斗組を置いて、この間に
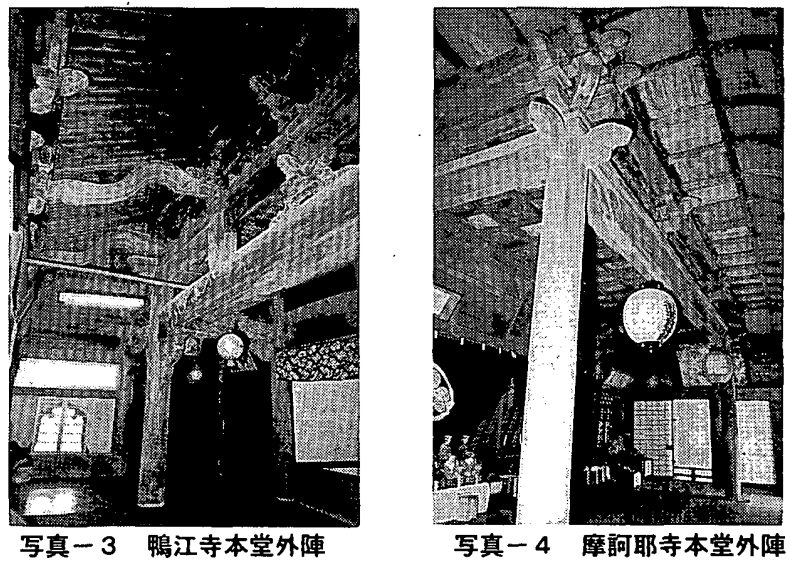


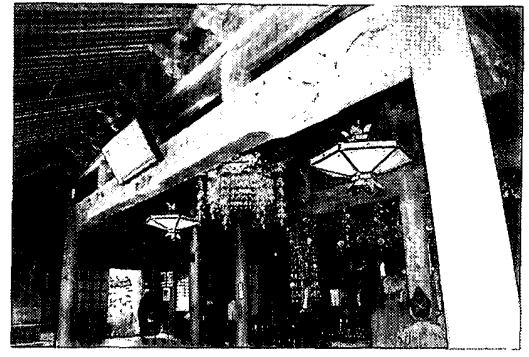

写真 -5 財賀寺本堂外陣

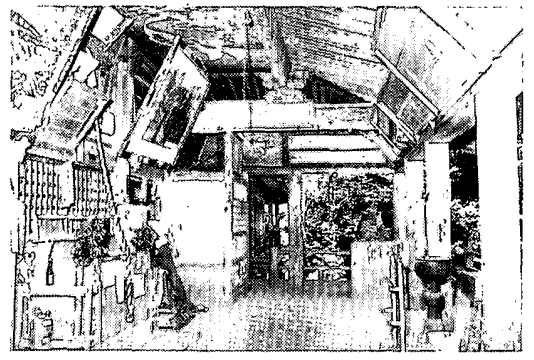

写嘪 -6 日龍蕃寺本堂外陣

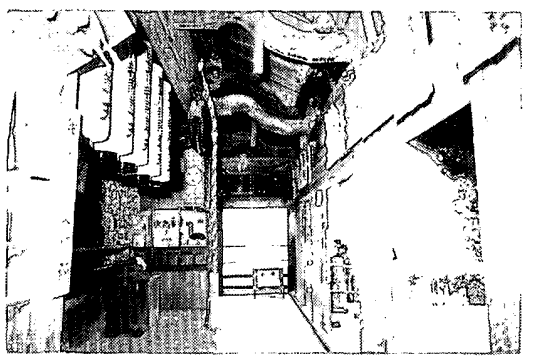

写真一 7 三明寺本堂外陣

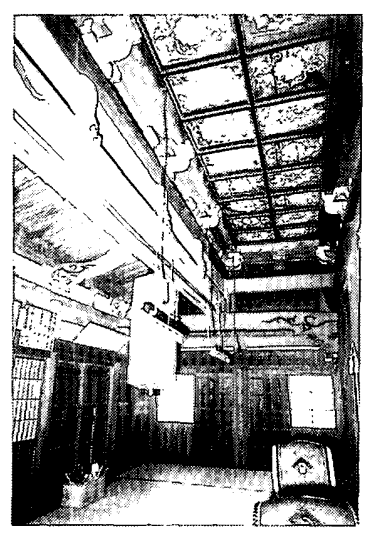

写真-8 始立寺本堂外陣

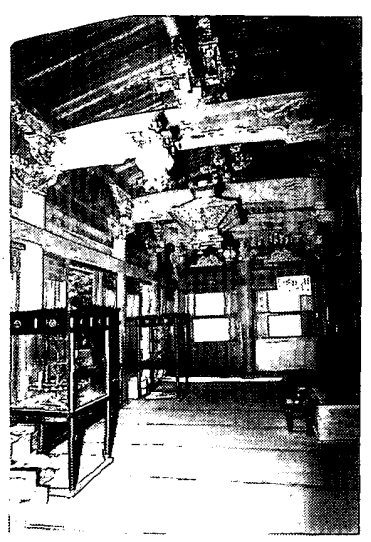

写真-12 横蔵寺本堂外陣

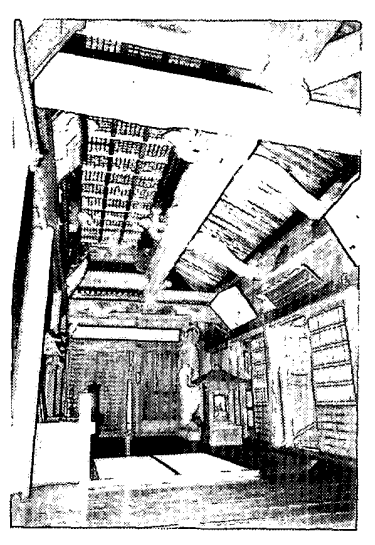

写真 -9 富賀寺本堂外陣

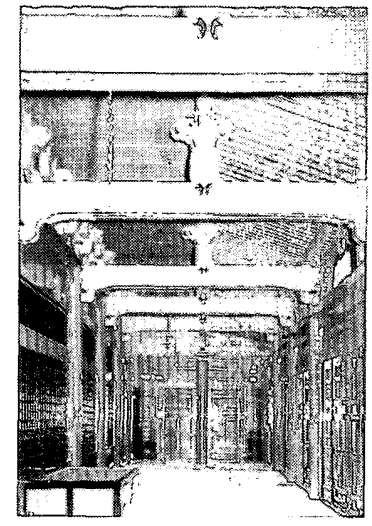

写真-10 金剛體寺本堂外陣

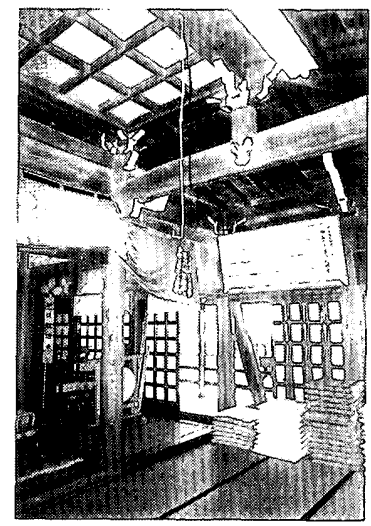

写真一11 実成寺本堂外陣

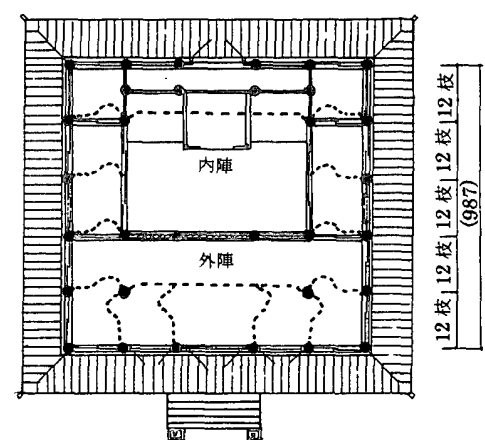

$$
\begin{aligned}
& \frac{12 \text { 枝迆校」 } 18 \text { 枝 } \mid 12 \text { 枝 } \mid 12 \text { 枝 }}{(1053) \mathrm{cm}} \\
& \text { 图一1 普門寺本堂平面図 }
\end{aligned}
$$

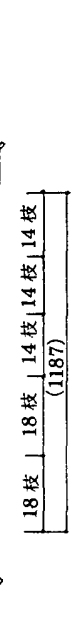

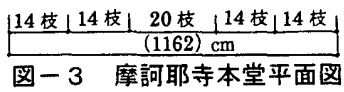

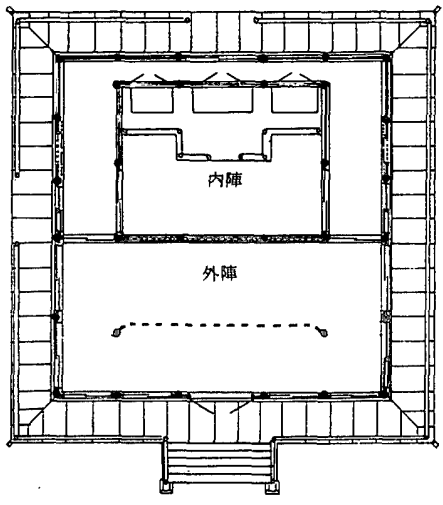

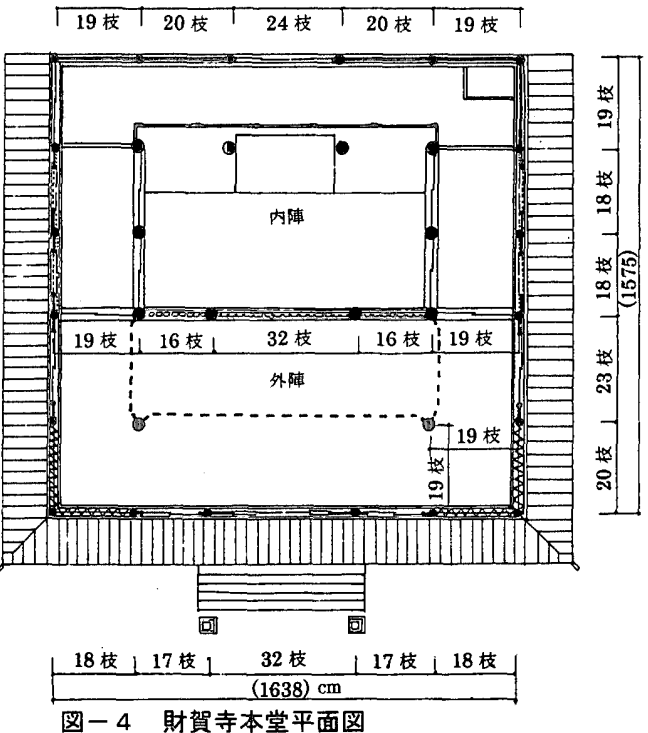

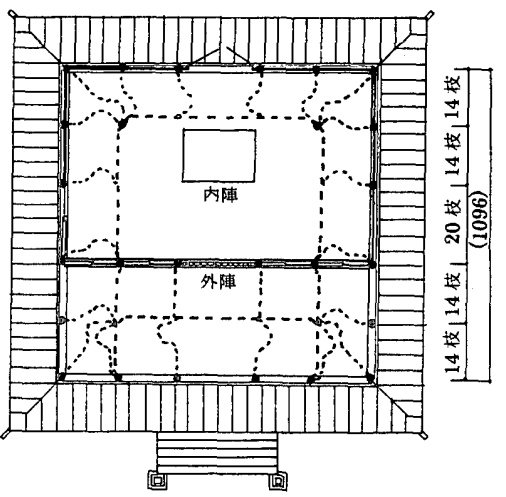

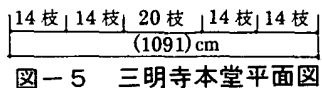

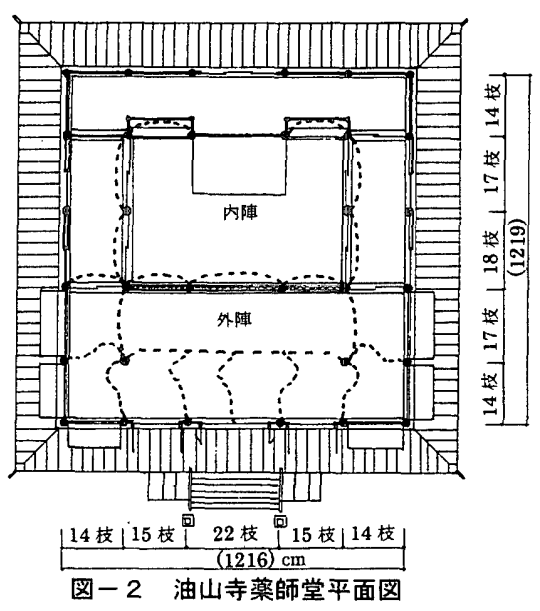




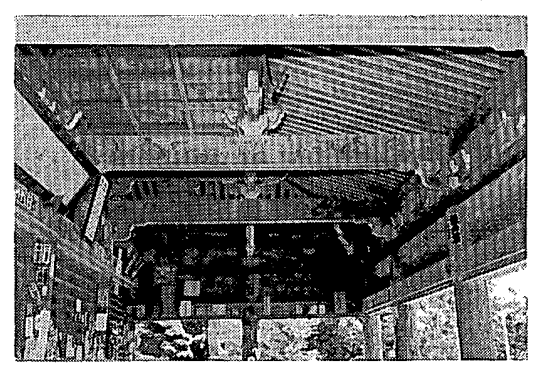

写真-13 大御堂寺本堂外陣

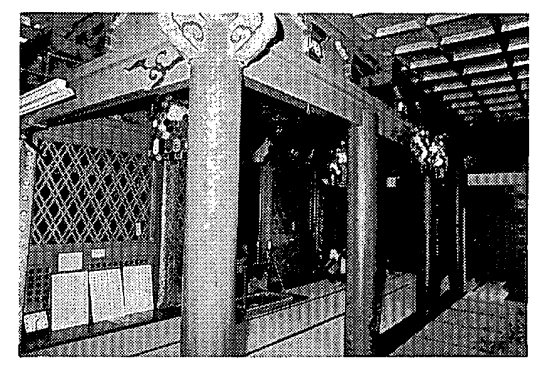

写真-16 大福寺本堂外陣

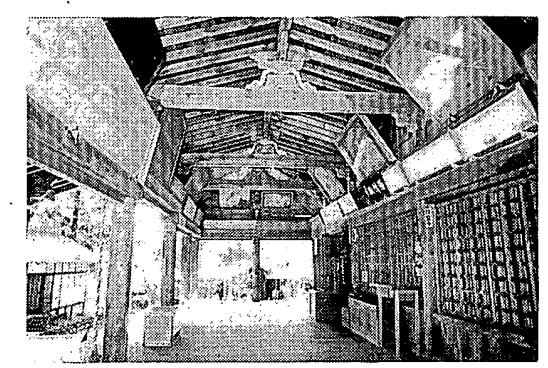

写真 -14 法明寺薬師堂外陣

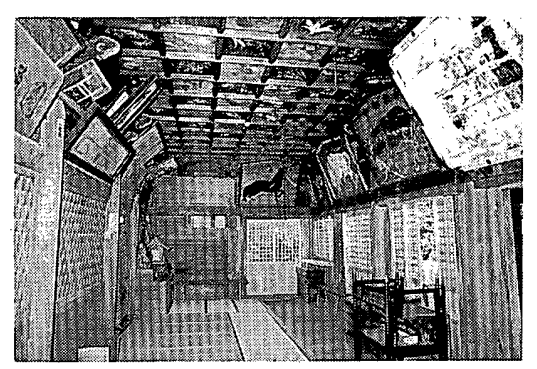

写真－17 東䚀音寺観音堂外陣

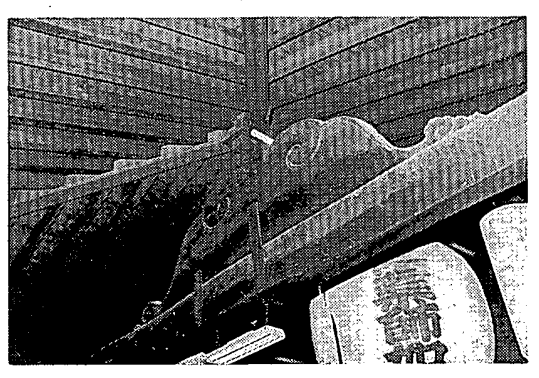

写真 -15 真福寺本堂外陣

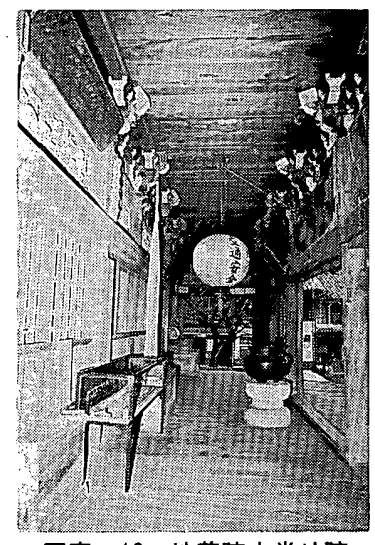

写真-18 地蔵院本堂外陣

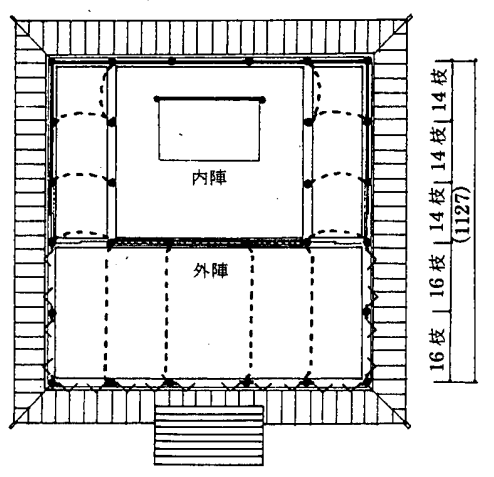

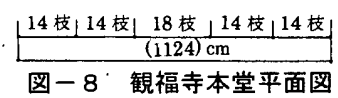

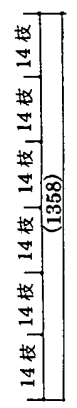

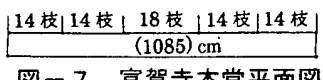

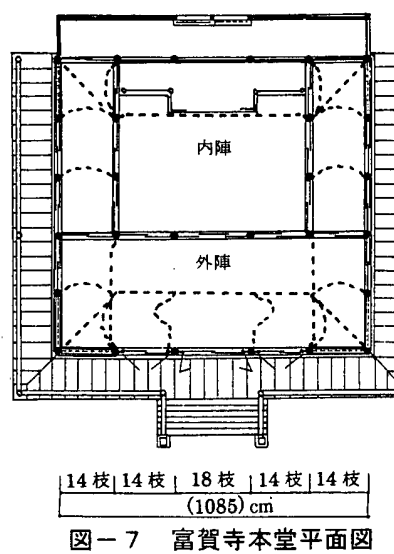

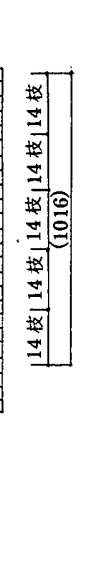

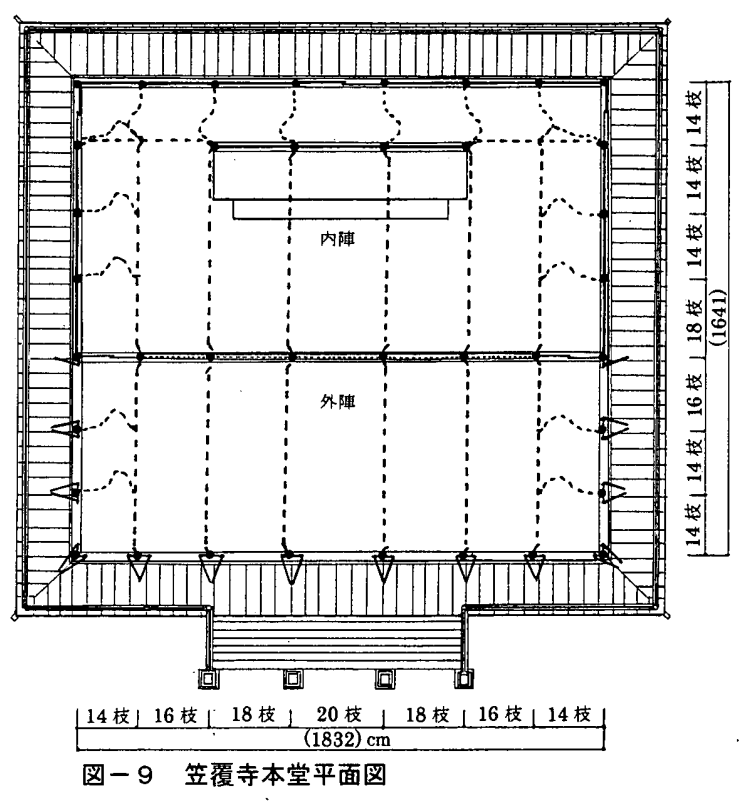

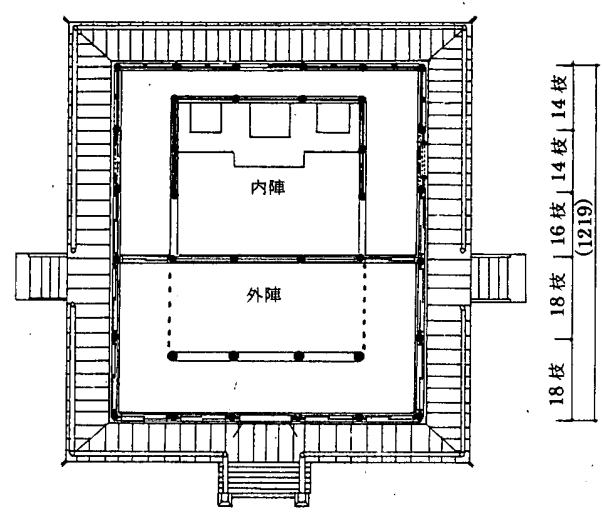

$\frac{\mid 14 \text { 枝」14枝|16枝|14 枝」14 枝 }}{\frac{(1095) \mathrm{cm}}{\text { 图-10 大福寺本堂平面図 }}}$

[写真 $-1 \cdot$ 写真 $-10 \cdot$ 写真 -19 は、修理工事報告書上り転载 $]$ *平面図脇の数字は各柱間の枝数を、（）内の数字は総長 $[\mathrm{cm}]$ を示す。 また、図中の点線は虹梁の架かる位㯰を表わす。 
析行 3 間虹梁を渡す架構法で、B-1 の形式と一致し、しかもこの 虹梁が直接、前方庇部分の化粧垂木を受けており、先述の日龍峯寺 と同様の古式な手法を採っている。

析行 3 閒大虹梁を 用いる仏堂が集中し てみられた東三河か ら遠江地域において も、その先駆けとな ったと考えられる遺 構が存在する。静岡 県湖西市の本興寺本 堂（写真-20）（天 文 21 年/1552) は、 法華宗の仏堂である が、この堂の外陣も 桁行 5 間 $\times$ 梁間 2 間 で、入側柱を立てず、 内陣正面雨端の身舎 柱から外陣前面側柱 一梁行 2 間虹梁を架 け、この 2 挺の虹梁 上に三斗組を載せて

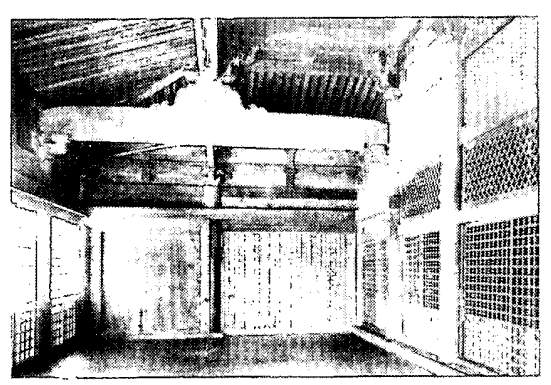
写真 -19 新長谷寺本堂外陣

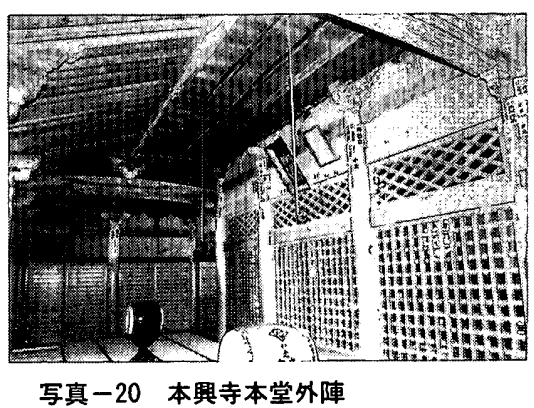
支点を設ける。ただし、ここではこの支点間に析行 3 閒虹梁ではな く、単純な析行 3 間の入側析を渡して、直接庇の化粧垂木を受けて いる。更に、三斗加らは外陣側面の側柱上斗栱へ海老虹梁を渡して いる。このように本興寺本堂の外陣では、未だ析行 3 間の虹梁は使 われていないものの、この架構が周辺の近世仏堂における外陣架構 の発展に少なから影響を及ぼしたことは十分に考えられよう。

こうしてみると桁行 3 間大虹梁は、当初、入側隅柱間に通された 頭貫であったり、梁行 2 間虹梁上の支点間に渡された入側析であっ たものが、次第に虹梁へ上変化していった可能性がある。そして、 これを内法に使用守るようにもなり、虹梁上に慕股や大瓶束・海老 虹梁・詰組を配したり、虹梁自体を大型化するなどの架構意匠の発 展を示した。また、禅宗様の影響は初期の遺構にもみられるので、 中世禅宗仏殿で既に用いられていた虹梁・大瓶束を使って柱を抜く 手法を密教系の仏堂にも応用し、析行 3 間虹梁の架構が発生した可 能性も考えられるが、その起源の究明は今後の課題としたい。

$\mathrm{B}-2$ : 外陣奥行 2 間で入側柱を立てず、梁行 2 間の虹梁を用い る堂

この種の堂は 5 棟あり、26 棟中最も建立年次の古い金剛證寺本堂 を始め、 4 棟が 17 世紀中期までの遺構である。また、その所在地 は、伊勢 1 棟・美濃 1 棟・尾張 3 棟で、三河・遠江を除く地域に限 られている。

金佣證寺本堂（写真－10）19は、、析行 7 間 $\times$ 梁間 6 間の七間堂 で、前方の梁間 2 間を外陣とする。外陣内には入側柱を 1 本も立て ず、内陣正面の各柱から外陣前面の側柱一梁行 2 間虹梁を架け、こ の 6 挺の虹梁上の中央に大瓶束と平三斗（拳鼻付）を置いて入側析 を受ける。また、両端の梁行 2 間虹梁の中央から外陣前面側柱人、 桁行と隅行の熬虹梁を架ける。天井は内陣前の 5 間 $\times 1$ 間の身舎部 分を鏡天井、その正側 3 方の庇部分を化精屋根裏とする。
実成寺本堂（写真-11）は五間堂で、内陣見付を 3 間とし、内陣 正面の両端柱から外陣前面の側柱八梁行 2 間虹梁を架け、この 2 挺 の虹梁上の化精隅木が真隅に納まる位置に大瓶束を立て、三斗枠肘 木を載せて入側析を受ける架構をみせる。また、側柱上の斗栱には 手挟を用い、天井は身舎部分を格天井、庇部分を吹奇せ俥木（後補 の可能性がある）の化粧屋根裏とする。架構は、先述の日龍峯寺本 堂の外陣とほほ共通するが、入側析（垂木摲）を虹梁としていない 点は古式で、本興寺本堂と一致する。

観福寺本堂 (図-8) ・横藏寺本堂 (写真 -12$) \cdot 大$ 御堂寺本堂 (写 真-13）の外陣ではい-゙れも、内陣正面の 4 本の柱から外陣前面側 柱八それぞれ梁行 2 間の虹梁を架け、この虹梁上の化粧隅木が真隅 に納まる位置に観福寺と大御堂寺では平三斗、横蔵寺では庇側に出 三斗、身舎側に出組を載せて入側析を受ける。天井は観福寺と大御 堂寺が身舎部分を格天井、横蔵寺が小組格天井とし、庇部分は 3 棟 とも化粧屋根裏とする。このように、外陣に梁行 2 間虹梁を 4 挺渡 し、この上に入側析を置く架構法は、中世仏堂 (五間堂) では最も 一般的な手法であり、当地方でも滝山寺本堂（愛知県岡崎市：室町 前期）20）之高田寺本堂（愛知県師勝町：室町中期）21)にみられる。 B-2':外陳奥行 2 問で入側柱を立てず、梁行 2 間の虹梁を用い、 外陣全体を舟底天井とする堂

この分類の遺構は、法明寺薬師堂（写真-14） と真福寺本堂（写 真－15）の 2 棟であり、両堂とも外陣の架構法は、内陣正面の 4 本 の柱から外陣前面側柱へそれぞれ梁行 2 間の虹梁を架ける点でB2 の堂と共通する。しかし、虹梁上の中央に法明寺では彫刻蟇股と 三斗枠肘木、真福寺では大柄な板暮股と大斗肘木を置き、その上に 化粧棟木を通して外陣全体を寄棟型の舟底天井としている。中世に おいても、外陣天井を舟底天井とする遺構 ${ }^{22}$ 注存在するが、その 数は少なく、このような礼堂風で復古的とむいえる構成の仏堂が、 当地方の近世仏堂においても採用されていたことは注目されよう。

$\mathrm{C}:$ 外陣奥行 3 間で入側柱を立てず、梁行 3 間の虹梁を用いる堂 これに分類されるのは、笠覆寺本堂（図一-9）1 棟である。この 堂は街行 7 間 $\times$ 梁間 7 間の七間仏堂であり、前方の 7 間 $\times 3$ 間を外 陣とし、外陣内には柱を 1 本も立てていない 23) ので、広々とした 礼扯空間を有する。外陣の架構は、内陣正面の 6 本の柱から外陣前 面の側柱へそれぞれ梁行 3 間の虹梁を渡し、この 6 挺の虹梁のうち 左右両端の虹梁上には側面側柱筋位置にそれぞれ平三斗を置き、前 寄りの平三斗で化粧隅木と入側通りの垂木措を受ける。また、これ らの各斗栱加外陣側面の側柱上の斗栱へ海老虹梁を架ける。天井 は内陣前の 5 間 $\times 2$ 間の身舎部分を格天井とし、その正側 3 方の庇 部分を化粧屋根裹とする。

外陣奥行 3 間で、梁行 3 䦎虹梁を用いた中世仏堂としては、長弓 寺本堂（奈良県生駒市：弘安 2 年/1279） ${ }^{24}$ )があげられる。この堂 では外陣中央に梁行 3 間虹梁を湾し、この 2 挺の虹梁下に入側柱を 支柱として立てている。この柱については、後補の指摘があるもの の、少なくとも当初の計画においては 3 間虹梁によって中央 2 本の 柱を抜き、広々とした外陣を造ろうとした意図が窥える。これ以降、 中世仏堂では梁行 3 間虹梁を使った遺構は存在せず、笠覆寺本堂は 近世の遺構ではあるが、同種の手法を採用し、しかも外陣内の柱を 全て抜き取るという架構をもった仏堂として注目される。 


\section{（2）外陣に架構を見せない仏堂}

$\mathrm{D}$ : 外陳奥行 2 間で入側柱 4 本を立て、架構を見せない堂

この分類に属するものは、大福寺本堂（図-10・写真-16）1. 棟 のみである。この堂は、外陣側面の柱閒寸法を広くとり、これとは 柱筋をずらして、外陣内に 4 本の入側柱を立てる。外陣は、内陣前 の 3 閒 $\times 1$ 間の身舎部分とその 3 方を取り囲む幅 1 間の庇で構成 され、入側柱間に汒無目敷居・頭貫 (側面は虹梁) ・台輪を通し、柱 上に出三斗、中備に薹束（側面は出三斗）を置く。天井は正側 3 方 の庇部分を格天井、内陣前の身舍部分を小組（菱格子）格天井とし、 天井高を低く抑え、外陣に架棈を見せない点や庇部分を化精屋根裏 としない点に特色がある。また、中世において既に、入側柱が抜か れていく傾向があることからみると、古風な印象を受けるが、近世 までこの伝統が存続したとみられる。

$\mathrm{E}:$ 外陣奥行 2 間で入側柱を立てず、架構を見せない堂

これに分類される堂には甲山寺護摩堂・東観音寺観音堂（写真一

17）・願成寺本堂の 3 棟がある。いずれも析行 5 間 $\times$ 梁間 2 間の外 陣一面に格天井を張り、虹梁による架構を採用しないことを特徵と

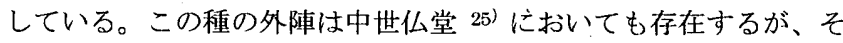
の数㴖僅かであり、室町時代以降の例としては、興隆寺本堂（愛媛 県丹原町：文中 4 年/1375）26) ・西国寺金堂（広島県尾道市：至徳 3 年/1386）27) ・観音寺金堂 [復原]（香川県観音寺市：室町前期）28）. 不動院本堂（奈良県大和高田市：文明 15 年/1483）29）がある。それ ぞれ外陣全体に鏡天井・格天井・棹縁天井・格天井を張っており、 西国寺と不動院では外陣内に斗棋も用いていない。中世の密教系仏 堂の外陣では架構や化精屋根裏を見せるものが主流であった中で、 これらは簡素で穏やかな扱いの外陣であり、甲山寺・東観音寺・願 成寺の各堂もこれらの流れを引くものであると思われる。

\section{$\mathrm{F}$ : 外陣奥行 1 間で、架構を見せない堂}

これに分類されるのは、地藏院本堂 ('写真-18) ${ }^{30}$ ) ·長久寺本堂・ 曼陀羅寺曼陀羅堂の 3 棟である。地蔵院本堂は伊勢地方の近世王間 仏堂の遺構で、外陣の奥行 1 間は、他の梁行柱間寸法より大きくと り、架構を見せることなく、外陣二面に鏡天井を張る。長久寺本堂 は、来迎柱以外を全て角柱とした簡素な仏堂で、やはり奥行 1 間の 外陣を他の柱間より広くとり、架構は見せず、一面に格天井を張る。 曼陀羅寺曼陀羅堂は、浄土宗寺院の仏堂で、外陣前面両端の柱間寸 法よりも外陣奥行の柱間を大きくとり、更に内陣正面の入側柱を外 陣前面の側柱と柱筋を揃えず、脇陣の見付幅を広くとり、内陣正面 も中 2 本の入側柱を拔いて見付 1 間としている。天井は小組格天井 を一面に張り、架構は見せていない。 3 棟とも、外陣の隅部分では 隅木が真隅に納まらない柱配置を採るが、梁組は全て外陣一面に張 られた天井裹に隠して処理している。

中世仏堂でこの種の外陣をもつものとしては、広島県の浄土寺阿 弥陀堂（貞和元年/1345）31）などがあげられるが、その数は少数で ある。この他、外陣の奥行を 1 間とする仏堂の中には、和歌山県の 長保寺本堂（延慶 4 年/1311） 32 ） のように、外陣の奥行を広い 1 間 とし、内陣正面の入側柱から外陣前面側柱一梁行虹梁を渡し、虹梁 上の隅木が真隅に納まる位置に支点を設け、内陣前の狭い身舎部分 を小天井とし、小天井以外を化精屋根裏の庇とする架構法をもつ堂 がある。中世では、和歌山・高知・福井 33 ）に遺構を残すが、東三 河の御津町に所在した大恩寺念仏堂 ${ }^{34)} も こ の$ 種の架構をもつ中世
仏堂の遺構であった。しかしながら、当地方の近世密教系仏堂の遺 構においては、この架構を採用した堂は存在していない。

もう一つ、奥行 1 間の外陣をもつ仏堂には、正面と再側面の庇幅 を同寸に揃え、隅木を真隅に納める構成の堂 35) があるが、この種 の堂も当地方の近世密教系仏堂には確翟できなかった。

\section{4. 大エ・エ医について}

最後に外陣の架構と大工・工质の関保についても若干触れておき たい。今回取り上げた 26 棟の仏堂のうち、棟札等によって工匠名 が知られるものは、金剛證寺本堂【山田下馬所賀兵衛宗廣・山田市 木彦兵衛家次】、観福寺本堂【名護屋 ·大塚弥市良重宅】、地蔵院本 堂 【久住十兵衛 - 伊藤六右衛門】、東観音寺観音堂【岡旧権右衛門義 直】、三明寺本堂【岡田善三郎成房】、油山寺薬師堂【邨松邑 - 兼子 忠衛門·山内蒌右門·山内権七郎】、大御堂寺本堂[野田彦兵衛清房]、 財賀寺本堂【岡田五左衛門之昌】の大工である。

このうち系譜が明らかなのは、岡田姓の大工である。岡田家は代々、 五左衛門を名乗る宫大この家柄で、初代は江州・近江八幡の生まれ で、徳川家康に従い三河に移ったという。その後、牛久保（豊川市） に拠点を置き、現 13 代当主まで、数多くの社寺建築を手掛けてき た。岡田家に残る文書 ${ }^{36}$ )によると、東観音寺・三明寺・財賀寺以 外にも、甲从寺護摩堂が岡田忠重、笠覆寺本堂が岡田蒠次、摩訶耶 寺本堂と富賀寺本堂がともに岡田富次・岡田之昌によるものとされ、 岡田大工が携わったとされる遺構は 26 棟中 7 棟にのぼる。

三明寺本堂・摩訶耶寺本堂・富賀寺本堂・財賀寺本堂は、東三河 · 遠江に所在する桁行 3 閒大虹梁を用いた外陣架構を有する仏堂であ り、笠覆寺本堂は尾張の遺構ではあるが、梁行 3 間虹梁を大胆に使 った七間堂で、いずれも豪放な架構を見せる点に共通の特徴がある。 三河・遠江地方を中心にみられたこの種の外陣架構法には、岡田大 工が樑く関わり、その発展の一翼を担っていたことが窅え、今後検 討を進めたい。

\section{5. むすび}

以上、本稿では東海地方に残る近世の七間堂・五間堂の外陣架構 の特徽とその変遷について考察し、近世密教系仏堂の特徴の一端を 明らかにした。それらを要約すると以下のとおりである。

(1) 東海地方の近世密教系仏堂の五間堂では、外陣の奥行を 2 間と するものが一般的であった。また、各仏堂の特色は、外陣の架 構法に顕著に現われていた。

(2) 当地方に扝汀る外陣架構の最大の特徴は、桁行 3 間大虹梁の使 用である。この架構には、a）入側柱を 2 本立てて、この間に 标行 3 間虹梁を渡すもの、b）入側柱を立てず、内陣雨脇柱筋 に梁行 2 間虹梁を渡し、この上に桁行 3 間虹梁を载せるものの 2 形式があった。更に桁行 3 閒虹梁上や入側隅柱から、正面側 面の側柱へ海老虹梁を架ける堂もあり、虹梁を二段・三段に積 み重ねた外陣架構を見せる仏堂が多くあった。しかも、これら の架構法は東三河・遠江地域に集中してみられた。

(3) 析行 3 間虹梁の発生要因の一つとして、当初入側筋の天井析 (垂 木掛）や頭貫であったものが、次第に装飾を主とした横架材と して用いられるようになったことが推察できる。そして、これ を内法に用いるようにもなり、禅宗様の技法等も積極的に取り 
入れ、虹梁上に慕股や大瓶束・海老虹梁・詰組を配したり、虹 梁自体を大型化するなど、架構意匠の発展を示した。

(4) 当地方には、中世にみられた、外陣に梁行 2 閒虹梁を 4 挺用い る架構をもつ仏堂や、舟底天井を張った仏堂、入側柱を全て残 す仏堂などもあり、古式な手法も存続した。また、外陣に全く 梁組を見せず、天井を一面に張った仏堂も少数ながら存在した。

(5) 当地方の近世密教系仏堂では、参拝者の目に触れ易い外陣の架 構表現に対する積極的な姿勢が認められた。その背景には、他 宗派の近世寺院本堂にみられる丸柱・斗栱・虹梁・彫刻等によ る荘厳化や、大工・棟梁による独自な建築表現の試みなど、近 世建築界の動向が少なからず影響を与えていたと考えられる。

今後は内陣架構や他の地域の遺構等についても考察をすすめ、近 世密教系仏堂の特質の解明を進めて行きたい。

謝辞 本稿を䌅めるに当たって、調査にご協力いただいた寺院及び 関係各位に記して感謝の意を表します。また、終始愁切丁寧なご指 導・ご教示を賜りました愛知工業大学工学部：小野木重勝博士並び に杉野丞博士に対し、深く感謝の意を表します。

注

1) 中世仏堂に関しては、先学による多大な研究成果がある。代表的なもの としては、伊藤延男博士の『中世和様建筑の研究』(彰国社 1961 年)・浅 野清博士の『鎌倉時代の仏堂』(佛教藝術五○毎日新閏社 1.962 年)・『宗 町時代の仏堂』(佛教囈術六三 毎日新聞社 1966 年)・関口欣也博士の『日 本建築史基礎資料集成七・仏堂IV』(中央公論美術出版 1975 年) - 田中淡 博士の『中世新様式における構造の改革に関する史的考察』(日本建築の 特質太田博太郎博士還暦記念諭文集 岩波書店 1976 年) ・ 鈴木嘉吉博 $士 の 『$ 中世の寺院建築 (大仏様・和様)』(文化財講座 日本の建築 3 中 世 II 第一法規 1977 年)・『和様建築の成立』（日本美術全集 $6 \cdot 1994$ 年) ・太田博太郎博士の『新和様の建築』(全集日本の古寺 $13 \cdot 1984$ 年)。 永井規男博士の『折哀様の建築』（全集日本の古寺 $18 \cdot 1985$ 年）・工藤圭 章博士の『和様加新和様・折婁様へ』（日本美術全集 $10 \cdot 1991$ 年）等 がある。

2) 近世密教系仏堂に関する論考としては、藤井恵介博士の『天台真言系寺 院建築』(奈良国立文化財研究所・第一回近世社寺建築研究集会記録 1988 年) ・浅川滋男博士の『天台真言系仏堂平面の類型とその地域分布』(奈 良国立文化財研究所・第一回近世社寺建築研究集会記録 1988 年) - 櫻井 敏雄博士の『西国三十三所寺院の構成と本堂の特質』(浅野清編・西国三 十三所䨝場寺院の総合的研究 中央公論美術出版 1980 年) などがあり、 個々の仏堂に関する論考では、『三遠地方における近世密教系仏堂の架構 について』(浅野清 日本建築学会大会学術講演梗概集 (以下大会梗概集) 1.980 年)・『近世遺構を通してみた中世仏堂発展の一過程』(山岸常人 大 会梗概集 1986 年)・和歌山県北部の仏堂の外陣架構について』（山岸常 人 大会梗概集 1989 年) ・『南寿山観音寺本堂』(小野木重勝 大会梗概 集 1990 年)・『愛媛県の近世寺院建築』(來木雅之 大会梗概集 1990 年) 等がある。しかしながら、近世密教系仏堂に関しては、未だその特質や 変遷過程を体系的に論ずるまでには至っていないと考える。

3) 拙稿恃本文記載順に、大会梗概集 1991 年・大会梗概集 1992 年・東海支 部研究報告集 1993 年・大会梗概集 1993 年・東海支部研究報告集 1994 年. 大会梗概集 1994 年・大会梗概集 1995 年・大会梗概集 1996 年。

4) 東海地方の各遺構に関しては、浅野清博士が『静阔県の近世社寺建筑』 (静岡県教育委員会 1979 年) ・要知県の近世社寺建築』(受知県教育委 員会 1980 年)・『岐皁県の近世社寺建築』(岐皋県教育委員会 1980 年) ・ 阣重県の近世社寺建筑』(三重県教育委員会 1985 年) の各報告書の中 で既に紹介しておられる。更に東三河と遠江の臬構を取り上げ、『遠地 方における近世密教系仏堂の架構について』(大会梗概集 1980 年) で、 その特徵について論じておられる。本稿では、対象笨进を広げ、東海地 方の七間堂・五間堂という括りでまとめ、各遗構の外陣架構を中心に考 察を行った。また、その後（1980 年以降）各都道府県で刊行された近世 社寺建築調查報告書に記載された遺構も含め、全国的な視野での比較検 討を試みた。特に桁行 3 間虹梁を用いた遺構（注 15）に関しては、他の 地域についても可能な限り実測調查を行った。

5) 本稿で三間堂を取り上げていないのは、三間堂は規模も小さく、また、 外陣をもたず堂内を一室とするものや、天井を張って架構を見せないも
のが多いため、外陣の架構法を考察する場合、七間堂・五間堂の架構と 三間堂の架構を単純に比較することは適切でないと考えたからでもある。

6) 本稿では天台・真言宗以外に、日蓮宗 2 棟・臨済宗 2 棟・曹洞宗 1 棟・ 浄土宗 1 棟の仏堂を取り上げた。表一 1 参照。

7) 金㴊證寺は、9世紀に空海が真言道場を開いたと伝える古刹で、室町初 期に中興され、臨済宗に改められた。

8) 実成寺は、元応元年(1319)の創立で、その後、日妙上人が現在の日蓮宗 に改宗したと伝える。

9 東観音寺は、古くは真言宗に属し、永禄年間 $(1558 \cdot 1569)$ に臨済宗に改め たといい、境内には重要文化財の多宝塔（大永 8 年頃）も残る。

10) 三明寺は、奈良時代の創建と伝え、旧宗派は不明であるが、室町時代に 中興されて曹洞宗になったといい、三重塔（享禄 4 年）と本堂内宮殷（天 文 23 年) はいずれも重要文化財に指定されている。

11) 妙立寺は日什上人が至徳 3 年(1386)に創立したという。

12) 曼陀羅寺は、元德元年(1329)後醍醐天皇の栜愿によって開かれたという。

13) 前掲、注 1)

14)「静岡県指定文化財 応賀寺薬師堂保存修理工事報告書」（1992 年）

15) 当地方以外の近世仏堂で桁行 3 間虹梁を外陣に用いる仏堂は、管見では、 和歌山県の青岸渡寺本堂 (重文 天正 18 年 $/ 1590$ 九間堂) ・兵庫県の一 乗寺本堂（重文 寬永 5 年/1628 九間堂）・愛媛県の西林寺本堂（元禄 13 年 $/ 1700$ 五間堂) ・ 三角寺本堂 (嘉永 3 年 $/ 1850$ 三間堂) ・新潟県の 菅谷寺不動堂 (明和 7 年 $/ 1770$ 五間堂) ・ 滋賀県の大岡寺本堂 (享保 13 年 $/ 1728$ 三間堂）の 6 棟である。重文を除く 4 棟は実測調査を実施。

16）桁行 3 間虹梁を用いる外陣架構については、既に浅野清博士が指摘され ておられる。(前揭、注 4)

17）「国宝善水寺本堂修理工事報告書」（1976 年）

18)「重要文化財新長谷寺本堂修理工事報告書」(1953 年)

19）「重要文化財金剖證寺本堂修理工事報告書」(1.994 年)

20）「新編岡崎市史建造物 18」（市史編集委員会1983 年)

21)「重要文化財高田寺本堂修理工事報告書」(1954 年)

22)この種の遗構としては、長寿寺本堂（滋賀県 : 鎌倉前期) - 善光寺本堂 (大分県: 建長 2 年/1250) - 妙楽寺本堂（福井県: 永仁 4 年/1296) - 石 手寺本堂 (愛媛県: 鎌倉後期) - 弥勒寺本堂 (兵庫県 : 康糜 2 年/1380) 浄光寺薬師堂 (長野県 : 応永 15 年/1408) - 内教寺大講堂 (兵庫県 : 永享 12 年 $/ 1440) \cdot$ 浄厳院本堂 (滋賀県: 室町後期) がある。

23) 現在は、外陣内に後補の柱列を設け、内陣を前方へ 1 間昖張する改造が なされている。

24）「日本建築史基礎資料集成七 ・ 仏堂IV」（1975 年 - 中央公論美術出版）

${ }^{25}$ ) この種の仏堂の古例としては、霊山寺本堂（奈良県：弘安 6 年/1283）・ 愛宕念仏寺本堂 (京都市 : 文保 2 年/1318) - 室生寺本堂（奈良県：鎌会 後期）があるが、これらの外陣空間は小組格天井や折上小組格天井を張 つた繊絊なもので、平安時代の邸宅系建築に類する意匠をもつ外陣であ り、室町以降のこの種の仏堂とは異なる系統であるように思われる。

26) [国宝興隆寺本堂修理工事報告書」(1938 年)

27)「重要文化財西国寺金堂・三重塔修理工事報告書」(1967 年)

28)「重要文化財観音寺金堂修理工事報告書」(1962 年)

29）「重要文化財不動院本堂修理工事報告書」(1967 年)

30)「重要文化財地蔵院本堂・鐘楼保存修理工事報告書」(1998 年)

31)「重要文化財浄土寺阿弥陀堂・露滴庵及び中門修理工事報告書」(1970 年) 浄土寺阿弥陀堂の他に注、石津寺本堂（嵫賀県：延文 4 年/1359)・ 利生護国寺本堂 (和歌山県 : 弘和元年/1381) - 瑞花院本堂 (奈良県: 嘉 吉 3 年/1443) - 法界寺本堂（京都府：康正 2 年/1456）・本蓮寺本堂（岡 山県 : 明応元年/1492) がある。

32）「国宝長保寺本堂修理工事報告書」（1972 年）

33) 和歌山県に法、長保寺本堂の他に松生院本堂 (焼失・永仁 3 年/1295) • 道成寺本堂（天授 4 年 $11378 ） ・$ 鞆沜神社大日堂（室町初期）が残る。高 知県には竹林寺本堂 (室町後期) と国分寺金堂 (永禄元年/1558) が残る。 福井県には中山寺本堂（室町前期）が残る。

34) 「重要文化財大恩寺念仏堂修理工事報告書」（1953 年）大恩寺念仏堂 は、平成 6 年 8 月 9 日火災により焼失。

35) この種の中世仏堂には、長福寺本堂 (奈良県 : 鎌倉末) ・勝常寺本堂 (福 舄県: 室町時代) - 地蔵院本堂（杤木県: 天文 11 年/1542) - 青蓮寺阿弥 陀堂（熊本県: 天文 11 年/1542）がある。

36) 安井四郎『官匠宮大工 岡田五左衛門 所蔵 古文書拔粋 目録』(私 家版: 1988 年) この他にも、仲金風『嵩山獅子正宗禅寺詰』(臨済宗 正宗寺 : 1981 年) ・『重要文化財三明寺塔婆修理工事報告書』(1951 年) ・ 『重要文化財東観音寺多宝塔修理工事報告書』(1959 年) に岡田大工に 関する記載がある。 